\title{
Differentiation Strategy and Organizational Culture: Case Study of Semarang State University
}

\author{
Qristin Violinda $^{1}$, I. Made Bayu Dirgantara ${ }^{2}$, Syuhada Sufian ${ }^{2}$ \\ ${ }^{1}$ Department of Economic \& Management, Huazhong Agricultural University, Wuhan, China \\ ${ }^{2}$ Department of Economic \& Business, Diponegoro University, Semarang, Indonesia
}

Email address:

qristinviolinda@ymail.com (Q. Violinda)

\section{To cite this article:}

Qristin Violinda, I. Made Bayu Dirgantara, Syuhada Sufian. Differentiation Strategy and Organizational Culture: Case Study of Semarang State University. International Journal of Economic Behavior and Organization. Vol. 4, No. 2, 2016, pp. 8-17. doi: $10.11648 /$ j.ijebo.20160402.11

Received: February 9, 2016; Accepted: February 18, 2016; Published: March 21, 2016

\begin{abstract}
Some scholar that differentiation strategic and organizational culture is one of the key in searching for competitive advantage and performance in strategic management. The differentiation strategy and organizational culture stands out as one of the components that are important to sustaining competitive advantage, performance, and a good reason for becoming a great institution and company. This paper aims at exploring contributions of differentiation strategy and organizational culture in competitive advantage and performance of Semarang State University (UNNES). 150 sample were collected from lecturer and employee functionaries of Semarang state University, and this sample using simple random sampling method. Samples were measured using Likert attitude scale and then the data were analysed using Structural Equation Model (SEM) AMOS 20.0 programme. Result shows that hypothesis one, two and three is accepted. Study finds that differentiation strategy do significantly positively affect competitive advantage, and performance. The better differentiation strategy and organizational culture will be enhance the competitiveness advantage and performance of Semarang state University.
\end{abstract}

Keywords: Differentiation Strategy, Organizational Culture, Competitive Advantage, Performance

\section{Introduction}

By the year 2012 every state and private universities in Indonesia are facing a new challenge of a very tight competition. The competition goes hand in hand with the implementation of university standards of PK BLU (Public Service Agency of Financial Management). Since the enactment of the PKBLU regulation, universities must be able to maintain their excellence and resale value in order to compete with others. The PKBLU university regulation aims to improve services to the public without seeking profit and also perform activities based on the principles of efficiency and productivity with flexible financial management. The competition however is come up because every competitor feel the opportunity to improve their position so that they must continue to compete with the hope to survive and be better than the others. The emerging of a new both public and private universities in Indonesia makes the competition getting tighter. Academic services, infrastructures, bureaucratic management and also employee productivity as well as teaching staff should be apriority of the development.

Data obtained from the Directorate General of Higher Education says the number of Higher Education (PT) in Indonesia shows a fairly rapid growth, especially in Private Colleges (PTS). By the end of 2010, State University (PTN) reached 108 and 3142 of PTS. These increasing number led to tighter competition. At the international level, Indonesian universities position can also be seen from the list of best universities in the world issued by the Time Higher Education Supplement (THES). he list issued by THES which published in London says there were no universities in Indonesia which entered the top 100 . However, for the first time in 2006 four State University (PTN) in Indonesia listed world's 500 best universities (Jawa Pos, 2006). It such an achievement though. Since there are many Indonesian state and private universities are not included in the list, so it is important to realize the un even quality of higher education in Indonesia. 
Development of Teachers' Training College into a university has deliver UNNES rank the 23 best universities in Indonesia and in world wide UNNES rank 2754 of 17.000 universities (htpp://www.webometric.info/methodology.html). Compared to other universities in Indonesia UNNES was far behind other colleagues such as former Teachers' Training College UNM (University of Malang), which was ranked 12 than UPI (University of Indonesia) which go to 16 as well as public universities in Semarang lik Diponegoro University which rank nine at National level. Based on these data UNNES ranks 23rd, and therefore UNNES should carefully set it self a better competitions trategies in educational institutions especially since the output of Webometric January 2011 shows UNNES position shifted to 28 . As revealed by Freed, Klugman, Seymour (1997) another challenges that must be faced by universities is the accountability to the greater community, financial barriers, greater expectationin improving access of cooperation, more attention on improving the quality, as well as the problems of education costs. Further more Blustain, Bonser, Rubach (2007) stated that the new competitive environment of colleges was formed, in which the college can not be separated from the influence of external events such as changes in demographics, technology, competition among institutions, and the global economy which is too complex. One form of strategy to win the competition that can be taken and used to improve the performance of a company or institution is a differentiation strategy.

Differentiation strategic studies conducted by Susanto (2001) states that the company can perform differentiation by identifying the source of competitive advantage that it may have a major distinguish feature owned by institution that does not owned by a competitor and communicating this thing to customers. A company or institution can offer to its customers the three terms of differentiation which is their product differentiation, terms of services and terms of images. A study o the differentiation strategy in sustaining competitive advantage in colleges also conducted Yeni (2007) where the research shows that universities which has a competitive strategy including the differentiation strategy will have a good performance of notice, consider, and respond to the latest trends so that the process it self will have an impact on the increasing performance of institutions. A similar study conducted Gordon (1991) regarding the improvement of companies performance stated that the success of a company depends on its success in creating a distinctive organizational culture as part of their strategic plan. Further more, he said that the compatibility between attitudes and behavior of employees with organizational culture has an effect on the performance of the employee. The effectivity of organizational culture will influence the effectivity of tasks implementation and management role which is related to the company's performance.

Organizational culture is an essential element in sustainable change and has major impact on the organizational or company. An organizational should change its culture and maintain a good organizational culture to be able to achieve rapid and sustainable changes. Organizational culture is aset of norms or behaviors and values that exist within a company or institution that must be adhered and practiced by the perpetrators of these organizationals to be able to interact with both the internal and external factors. According to many companies and institutions which couldn't survive as a result of their leader's ignorance and misunderstanding to the company culture. Specific failure of the organizational culture will result in confusion or uncertainty and conflict of the basis function and the importance of an organizational. Brien (1998) says that organizational failures can often be traced from the organizational culture and the failure of leaders to promote the ideas and practice of organizational ethics.

Based on this background, this study to address these research gaps to explores the definition and effects of differentiation strategic and organizational in the emerging semarang state university. As such, this research contributes to existing literature by entailing the new research context: case study of semarang state university clarifies the debates on the effect of differentiarion strategic, organizational culture in sustaining competitive advantage and performance university. This paper is organized as follows; section 2 presents focal constructs of interest and the relationship among them and develops related hypotheses. Section 3 provides the study methodology, and section 4 shows the empirical result. Finally, the paper present discussion and conclusion.

\section{Literature Review and Hypothesis}

\subsection{The Effect of Differentiation Strategic on Competitiveness Advantage}

Differentiation strategy is an act of designing a set of meaningful differences to distinguish the company's offering of foreign deals. Kutcher (2000) said that companies often feel satisfied and successful when differentiation strategy applied has created a product regardless whether the uniqueness is worth or not for the buyer. The company is successful in conducting differensatiation strategy when it managed to show the uniqueness that is considered important by the buyer, other than just alow price quote. Differentiation allows the company to offer a high price (premium price), sell more products at a specified price or obtain an equivalent number of benefits.

Differentiation allows the company to gain a competitive advantage if successful premium price offere disgreater than the cost to obtain uniqueness. Differentiation strategy is divided into five indicators (Kutcher, 2000):

1. The shape of the product: views ofe xcellence function and aesthetic value

2. Marketing channels: the desire to act at the level of demands which is responsiveness, information and the needs of consumers.

3. Service and support: servicing the consumers on things they need.

4. Image: clearly explain to the consumers about the product 


\section{Price: do the pricing strategy}

This is supported by studies of Sashi \& Stern (1995) which showed a significant relationship between differentiation strategy and performance. According Porter (1980) generally, there are three potentially successful strategies too perform firms in an industry including low cost strategy, differentiation strategy and focus strategy. Differentiation strategy is the most profitable strategy, according to research of MacMillan \& McGrath (1997) which states that the differentiation strategy is based on offering the customers something valueable that is not owned by a competitor. Differentiation strategy is an integrated series of actions designed to produce goods or services that are considered different by the customers in things that are important to them (A. hitt \& Hoskinson; 2001).

Differentiation strategy can generate position in the customer's perception of the value offered and produce a specific competitive advantage (Ferdinand, 2003). This creates unique position in the face of competitors. Excellences can only be achieved by developing a distinc and favorable differentiation strategy from its competitors. Success of a company in achieving competitive advantage is influenced by the competitive strategy of the company it self. Competitive advantage derived from the differentiation strategy is expected to produce a good performance (Ferdinand, 2003). Performance of the company is a concept to measure the achievement of a product there fore differentiation strategy can be one of the main concerns of each company in order to achieve the company's performance (Porter, 1980).

H1: The better differentiation strategy, the better the university's competitive advantage achieved.

\subsection{The Effect of Organizational Culture on Competitiveness Advantage}

Organizational culture is an effective resource in implementing strategies for the management and upgrading the performance of employees (Lawyer, 1985 Denison, 1990). Kotler and Hesket (1997) says that a strong organizational culture can affect both individual and company performance, even in a competitive environment it may have greater influence than other factors such as organizational structure, financial analytic tools and leaderships. Then some studies suggest the influenc eof organizational culture on behavior and work ethic. Research conducted by Walton and Lauterin Denison (1990) concluded that organizational culture turned out to be an effective strategy for the management of the encouraging performance of employees to improve company sustaining advantage. Lado \& Wilson (1994) stated that the performance of human resources as member of the company is potentially helps the companies to achieve a competitive advantage. Human resource is an asset that is hard to duplicate, rare, and particularly provide a competitive advantage for its employees (Astuti, 2003). Further, he said that well developed human resource system with in the company could be an intangible asset and are able to create value when applied in organizational's operational systems, thus lower in imitability of the company, able to improve company's performance which in turn will increase the company's competitive advantage.

Three important forces in maintaining organizational culture is the selection, top management measures and methods of socialization. The concept of corporate culture is now growing more than just identity and slogan. The corporate culture has become the new paradigm. According Susanto (2000), it has a function as a tool to achieve the purpose of business development and human resource development in order to be more qualified and as a main stay of competitiveness. The statement said that the organizational culture associated with the performance is acceptable because culture plays an important role in generating competitive advantage (Scholz, 1987). A research by Jill Mc. kinnon (2003) found that results orientation, aggressiveness and adaptive are indicators of organizational culture.

H2: The better of the organizational culture, the better the university's competitive advantage achieved.

\subsection{Competitive Advantage of University Performance}

Day \& Wensley (1988) says that the competitive advantage can be obtained by implementing strategy to survive, is a forms of a strategy to assist the company in maintaining its viability. This opinion was supported Ferdinand (2003) whom states that in a competitive market, the ability of the company to produces performance depends on the degree of competitive advantage. Because basically every company wants to perpetuate its existence, its competitive advantage must be sustainable.

Based on there source based-theory, Barney (1991) and Hoffman (2000) proposed the normal definition of competitive advantage, namely on -going excellence achieved by implementing the achievement of a unique values strategies that is not owned by competitors. Further, he said that the company is said to have a competitive advantage if it'sable to create value at a time that is not being implemented either by competitors or potential competitors and other companies are unable to mimic the advantages of this strategy.

According Fahy and Smithee (1999) if competitive advantage were obtained the better performance can be achieved, with the achievement of competitive advantage by providing more value to customers company is expected to achieve the performance measures conventionally such as a market based performance (market share, customer satisfaction) and financial based performance (ROI).

Research gaps of this study is an extension of the variables that affect company's performance improvement, which according to research by Chao Shun Huy (1991) and Sashi and Stern(1995) showed significant relationship between differentiation strategy and performance. Another study conducted Fornee (1992) developed the influence of differentiation strategy in improving the performance of the company to achieve competitive advantage, where there is 
the influence of the company's performance on competitive advantage and this supported by Barney (1991). Another study shows that variables affect the performance of the company is the culture of the organizational. According to research O'Reilly (1991), Peters; Waterman; Harvey and Bown (1996) said that corporate culture is essential for companies to improve their performance, where organizational culture, leadership, commitment of top management as the independent variable and the performance as dependent variables, as well as research by Robbins (1996) noted that every institutions hould be able to manage the culture well to achieve high performance. Therefore, the authors wanted to examine how the effect of differentiation strategy and organizational culture as a variable independent and competitive advantages as an dependent variable to achieve performance university. Besides, similar studies examine the effect of the differentiation strategy and organizational culture on competitive advantage in achieving performance in the field of business services has not been done before so that further research needs tobe done.

Institutional performance is company achievement measured from performance outcome. Most researchers agree that the performance measurement of institutions is not only using a single measure. Profitability is still considered to be the main aspects of the company performance measurement, but still not sufficient to explain the effectivity of the institutions in general. Every institution has a goal to grow and have long term viability. Global era with a highly competitive business environment requires very different management system than the past (Mulyadi, 2001). The system must be able to accurately describe the new business environment faced by enterprises today and the future.

Institutional performance has always been measurement of the institutional activities success so that it takes necessary methods to measure it (Kaplan \& Norton, 1996). The importance of that is because the performance is a difficult concept, both the definition and measurement (Keatsand Hitt, 1988). Hongren (1992) says that the purpose of performance measurement is to be able to compare the achievement of the company now days with the previous year's or competitor company's accomplishment, and by that, revision of irrelevant policies can be done and have a better future achievement.

H3: The better competitive advantage, the better the university's performance

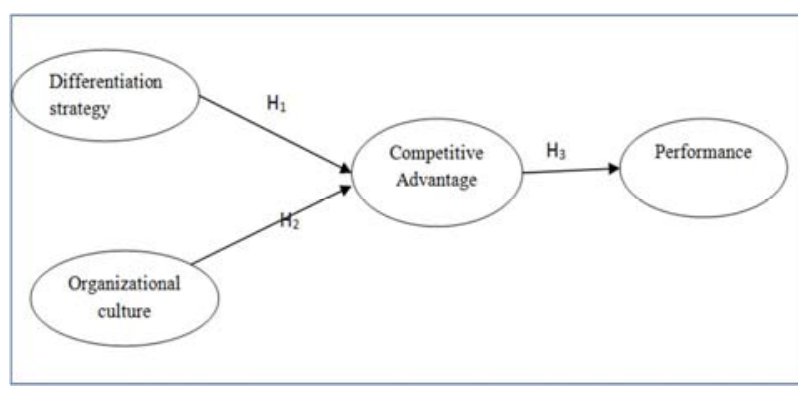

Figure 1. Conceptual model of the study.

\section{Research Design}

\subsection{Sample and Data Collections}

The primary data source in this study was obtained directly from the respondents, namely rector, provost, headsections, deans, dean assistants and head of programs on the criteria of employee and Lecturer at the University of Semarang (UNNES).

Table 1. Officials directories of Semarang state University.

\begin{tabular}{|c|c|c|}
\hline NO & Directories & Totally \\
\hline 1 & Rectorat official & 5 \\
\hline 2 & $\begin{array}{l}\text { Academic administration officials, students affairs and } \\
\text { cooperation. (BAAKK) }\end{array}$ & 10 \\
\hline 3 & General administration and personnel bureau (BAUK) & 8 \\
\hline 4 & Planning and financial administration bureau (BAPK) & 10 \\
\hline 5 & Community service agencies (LP2M) & 18 \\
\hline 6 & Education and professional development institute (LP3) & 18 \\
\hline 7 & Internal audit official & 2 \\
\hline 8 & Quality assurance agencies & 2 \\
\hline 9 & Businnes developer unit & 5 \\
\hline 10 & Library official unit & 2 \\
\hline 11 & $\begin{array}{l}\text { UPT center of information technology and } \\
\text { comunication }\end{array}$ & 2 \\
\hline 12 & UPT relationship comunities & 2 \\
\hline 13 & Procurement services unit & 2 \\
\hline 14 & Education faculty official & 29 \\
\hline 15 & Language and art faculty oficial & 39 \\
\hline 16 & Social science official & 24 \\
\hline 17 & Mathematic and sains faculty & 27 \\
\hline 18 & Faculty of technic official & 33 \\
\hline 19 & Faculty of sports official & 22 \\
\hline 20 & Faculty of economic official & 18 \\
\hline \multirow[t]{2}{*}{21} & Faculty of law official & 12 \\
\hline & Totally & 290 \\
\hline
\end{tabular}

Source: book of UNNES directory 2011

The population in this study covering Semarang State University officials (staff and faculty) with the number 290 in the central office of the rectorate and eight faculty also one graduate program. The sample that amounted to 150 people with diverse characteristics of respondents based on status or position held. Questionnaires were given to a total 150 respondents. All returns and deserves to be a source of data because all research questions were well and fully answered. To assess the content vaidity of the survey item, survey questions were pre-tested and refined through application to convenience-sampled 290 selected using convenience sampling from among official directories of Semarang state University (UNNES), Indonesia. The aim was to assess both questionnaire and the administration process. The respondent were given one month to respond, and 19 complete responses were obtained. Ambiguities in the wording of the questionnaire were identified and clarified based on the subject responses. Overall the rspondents exhibited no difficulty on completing and returning the questionnaire.

This study follow Kline (1998) in checking for missing data points, normality of the data distribution and outliers. This investigation uses mean substitution to deal with missing data. To ensure data robustness, Mahalanobis 
distance is used to check for outliers. The Mahalanobis distance is between 0 and 1 for all observations, indicating that the data conform to normality and the data set contains no problems with outliers (Kleinbaum, Kupper, \& Muller, 1998).

\subsection{Analysis Technique}

Analysis tools using Structural Equation modeling (SEM) with AMOS 20.0. The first step is to test the indicators through confirmatory factor analysis conducted on exogenous and endogenous varibles. The second step, performan analysis of the full model and Structural Equation Models (SEM) that are useful for hypothesis testing.

The reason is that SEM is a set of statistical techniques that allow the measurement of a series of relationships that are simultaneously relatively "complex". According to Ferdinand (2006) SEM allows researcher to answer the research questions that are regressive and dimensional. SEM also can identify the dimensions of a concept or construct and at the same time measure the effect or the degree of relationship factor dimensions to be identified.

To create a complete modeling SEM the following steps needs to be done (Ferdinand, 2006). The steps is from Developing Theory-Based Model (DTBM), measurement model, univariate outliers evaluations, normality test, reliability, validity and the final step is to interpretations and modify a model whether it qualify the test or not. The need to modified models can be seen from the number of residuals generated by the model. Modifications need to be considered when the residual amount greater than $5 \%$ of all residual $>$ 258 , then considering adding a new channel to the model estimates to modify.

\subsection{Measures}

Questions in our survey, which also provides participants with definitions of each construct. Our survey has a combination of reflective and formative measures. Reflective indicators are determined by the construct and, hence, covary at the level of that construct. In contrast, formative measures are expressed as a function of the items; that is, the observed items form or precede the construct. Because the latent variable is viewed as an effect rather than a cause of the formative indicators, these indicators are not necessarily correlated (Hulland, 1999).

The study models differentiation strategic and organizational culture as a independent variable construct. Differentiation strategic with five formative dimensions (Product, Serve and support, Personel, Chanel, Image) and for organizational culture have seven dimensions (professionalism, integrity, regularity, Trust, care, controlling, openness). This study also uses dependent variable. The variable is competitive advantage with four formative dimension (Financial, customer, internal business process, Learning and growth) and performance variable also with four variable (Durability, Immitability, transferability and replicability). The literature review, case study, and expert panel also helped in creating a list of elements the value propositions of companies in the selected sample. Participants reported the degree to which the items were incorporated as part of their university mission and value proposition.

\section{Result}

\subsection{Univariate Outliers Evaluations}

The existence of univariate outliers is tested by analyzing the standardized value (Z-score) of the data used. Standardized value has an average (mean) zero with a deviation standard (DS) of one. Limit values of z-score according to Hair et al (2010) were in the range 3-4. If there is a $\mathrm{Z}$-score is in the range \pm 3.00 , it will be categorized as a univariate outlier. The results of data processing to test whether there is an outlier is presented in Table 2:

Table 2. Univariate outlier analysis results.

\begin{tabular}{|c|c|c|c|c|c|}
\hline & $\mathbf{N}$ & Minimum & Maximum & Mean & Std. Deviation \\
\hline Zscore(X1) & 150 & -2.70917 & 1.60251 & .0000000 & 1.00000000 \\
\hline Zscore(X2) & 150 & -2.88694 & 1.42193 & .0000000 & 1.00000000 \\
\hline Zscore(X3) & 150 & -2.50297 & 1.43871 & .0000000 & 1.00000000 \\
\hline Zscore(X4) & 150 & -2.12524 & 1.47686 & .0000000 & 1.00000000 \\
\hline Zscore(X5) & 150 & -2.04289 & 1.40794 & .0000000 & 1.00000000 \\
\hline Zscore(X6) & 150 & -2.62029 & 1.39856 & .0000000 & 1.00000000 \\
\hline Zscore(X7) & 150 & -2.49672 & 1.25211 & .0000000 & 1.00000000 \\
\hline Zscore(X8) & 150 & -2.27024 & 1.25498 & .0000000 & 1.00000000 \\
\hline Zscore(X9) & 150 & -2.39345 & 1.36983 & .0000000 & 1.00000000 \\
\hline Zscore (X10) & 150 & -2.30668 & 1.80017 & .0000000 & 1.00000000 \\
\hline Zscore(X11) & 150 & -2.48300 & 1.74939 & .0000000 & 1.00000000 \\
\hline Zscore(X12) & 150 & -2.73035 & 1.63821 & .0000000 & 1.00000000 \\
\hline Zscore(X13) & 150 & -2.30930 & 1.17907 & .0000000 & 1.00000000 \\
\hline Zscore(X14) & 150 & -2.23462 & 1.41672 & .0000000 & 1.00000000 \\
\hline Zscore(X15) & 150 & -2.36568 & 1.49981 & .0000000 & 1.00000000 \\
\hline Zscore(X16) & 150 & -2.72026 & 1.59761 & .0000000 & 1.00000000 \\
\hline Zscore(X17) & 150 & -2.87559 & 1.58269 & .0000000 & 1.00000000 \\
\hline Zscore(X18) & 150 & -2.33190 & 1.43937 & .0000000 & 1.00000000 \\
\hline Zscore(X19) & 150 & -2.24448 & 1.31819 & .0000000 & 1.00000000 \\
\hline Zscore (X20) & 150 & -2.33849 & 1.67362 & .0000000 & 1.00000000 \\
\hline $\begin{array}{l}\text { Valid N } \\
\text { (listwise) }\end{array}$ & 150 & & & & \\
\hline
\end{tabular}

Source: Primary data, proceed, 2011

The table above shows that the value of the Z-score of each data $\mathrm{x} 1$ to $\mathrm{x} 20$ on the minimum and maximum column shows no figures that more than $\pm 3,00$. This means that the data used in this study is free of univariate.

\subsection{Normality Test}

The presence of multivariate outliers can be seen from Mahalanobis distance. Mahalanobis test can be done by calculating the Mahalanobis distance through AMOS 16. Here are the results of Mahalanobis calculation presented in Table 3: 
Table 3. Multivariate outliers analysis.

\begin{tabular}{llll}
\hline Observation number & Mahalanobis d-squared & p1 & p2 \\
\hline 83 & 39,064 & 0,007 & 0,481 \\
80 & 36,729 & 0,013 & 0,36 \\
34 & 36,102 & 0,015 & 0,189 \\
89 & 32,218 & 0,041 & 0,591 \\
55 & 31,048 & 0,055 & 0,642 \\
90 & 30,686 & 0,059 & 0,55 \\
53 & 30,665 & 0,06 & 0,39 \\
94 & 30,527 & 0,062 & 0,277 \\
57 & 30,014 & 0,07 & 0,261 \\
51 & 29,405 & 0,08 & 0,279 \\
$\ldots$. & $\ldots$ & $\ldots$. & $\ldots \ldots$ \\
$\ldots$. & $\ldots$. & $\ldots$. & $\ldots \ldots$ \\
48 & 12,802 & 0,886 & 0,281 \\
15 & 12,682 & 0,891 & 0,222 \\
25 & 12,644 & 0,892 & 0,143 \\
77 & 12,186 & 0,91 & 0,19 \\
91 & 12,067 & 0,914 & 0,129 \\
42 & 11,533 & 0,931 & 0,174 \\
5 & 11,507 & 0,932 & 0,085 \\
21 & 10,879 & 0,949 & 0,113 \\
26 & 10,359 & 0,961 & 0,096 \\
44 & 10,028 & 0,968 & 0,037 \\
\hline
\end{tabular}

Source: Primary data, proceed, 2011
The results of data processing showed that the minimum Mahalanobis distance is 10.028 and the maximum is 39.064 . Based on the chi-square value of 45.31475 with 20 degrees of freedom (the number of indicators) at a significant level of 0.001 there was no outliers.

\subsection{Reliability and Variance Extract}

Reliability test informs how far a measuring instrument can give relatively similar results when remeasuring the same object of research. The minimum reliability value of latent variable forming dimension received ie 0.70. As construct reliability test result was presented, variance extract test results was also shown in tabular form. To simplify the display, it can be seen from the table that the value of construct reliability is above the upper limit of ie 0.70 and variance extracted values are all above ie 0.50 . Generally it can be concluded that the indicators used as an observed relative variables explains the formation of the latent variables.

Table 4. Reliability test and variance extract

\begin{tabular}{|c|c|c|c|c|c|c|c|c|}
\hline Variabel & & Loading & Loading $^{2}$ & Error & ej & $\sum$ loading & Construct & Variance \\
\hline & & & & & & & Realibility & Extract \\
\hline Differentiation & $\mathrm{x} 1$ & 0,739 & 0,546 & 0,546 & 0,454 & 8,130 & 0,893 & 0,626 \\
\hline \multirow[t]{5}{*}{ Strategy } & $\mathrm{x} 2$ & 0,830 & 0,689 & 0,689 & 0,311 & & & \\
\hline & $\mathrm{x} 3$ & 0,805 & 0,648 & 0,648 & 0,352 & & & \\
\hline & $\mathrm{x} 4$ & 0,793 & 0,629 & 0,629 & 0,371 & & & \\
\hline & $x 5$ & 0,786 & 0,618 & 0,618 & 0,382 & & & \\
\hline & Amount & 3,953 & 3,130 & 3,130 & 1,870 & & & \\
\hline Organizational & $\mathrm{x} 6$ & 0,833 & 0,694 & 0,694 & 0,306 & 10,815 & 0,893 & 0,545 \\
\hline \multirow[t]{6}{*}{ Culture } & $\times 7$ & 0,740 & 0,548 & 0,548 & 0,452 & & & \\
\hline & $\mathrm{x} 8$ & 0,743 & 0,552 & 0,552 & 0,448 & & & \\
\hline & $\mathrm{x} 9$ & 0,798 & 0,637 & 0,637 & 0,363 & & & \\
\hline & $\mathrm{x} 10$ & 0,672 & 0,452 & 0,452 & 0,548 & & & \\
\hline & $\mathrm{x} 11$ & 0,653 & 0,426 & 0,426 & 0,574 & & & \\
\hline & $\mathrm{x} 12$ & 0,712 & 0,507 & 0,507 & 0,493 & & & \\
\hline \multirow[t]{5}{*}{ Competitive advantage } & $\mathrm{x} 13$ & 0,695 & 0,483 & 0,483 & 0,517 & 6,558 & 0,875 & 0,639 \\
\hline & $\mathrm{x} 14$ & 0,737 & 0,543 & 0,543 & 0,457 & & & \\
\hline & $\mathrm{x} 15$ & 0,841 & 0,707 & 0,707 & 0,293 & & & \\
\hline & $\mathrm{x} 16$ & 0,908 & 0,824 & 0,824 & 0,176 & & & \\
\hline & Amount & 3,181 & 2,558 & 2,558 & 1,442 & & & \\
\hline \multirow[t]{5}{*}{ Performance } & $\mathrm{x} 17$ & 0,837 & 0,701 & 0,701 & 0,299 & 6,539 & 0,873 & 0,684 \\
\hline & $\mathrm{x} 18$ & 0,762 & 0,581 & 0,581 & 0,419 & & & \\
\hline & $\mathrm{x} 19$ & 0,907 & 0,823 & 0,823 & 0,177 & & & \\
\hline & $\mathrm{x} 20$ & 0,660 & 0,436 & 0,436 & 0,564 & & & \\
\hline & Amount & 3,166 & 2,539 & 2,539 & 1,461 & & & \\
\hline
\end{tabular}

Source: primary data proceed, 2011

\subsection{Confimactory Factor Analysis}

Measurement model was tested using confirmatory analysis and was analyzed by Structural Equation Model (SEM) for the causality models between variables that affect and are affected by the level of differentiation strategy, organizational culture has positive effects on the competitive advantage and performance of the university, where the results of the analysis have met the criteria Goodness of FitFull Model with chi-square value $=170.733$; probability 0,384.; GFI $=0.852 ; \mathrm{AGFI}=0.812 ; \mathrm{TLI} ; 0,995 ; \mathrm{CFI}=0.995$; $\mathrm{CMIN} / \mathrm{DF}=1.029$; RMSEA $=0.017$. Based on the analysis of data it can be concluded that the model can be accepted.

The processing results of the confirmatory factor analys is to all models indicate that all the indicators used to establish 
the model of this research has met the criteria for goodness of fit. All the goodness of fit values shown in the result column has met the conditions where these values fit in with cut of value column. This means constructs used to establish are search model has met the eligibility criteria of a model.

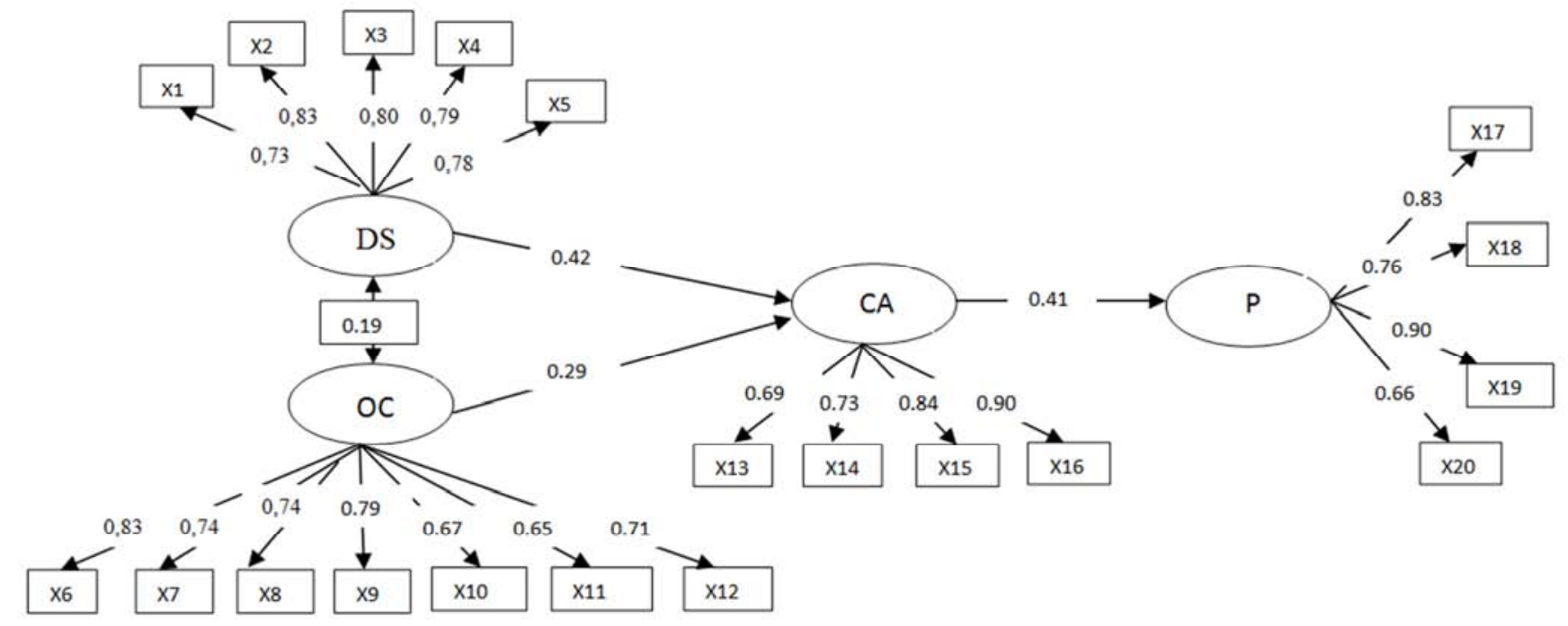

Source: Primary data, proceed, 2011

Figure 2. Full Model Confirmatory Analysis.

\subsection{Hyphotesis Testing}

Table 5. Hypothesis Testing

\begin{tabular}{llll}
\hline & HYPOTHESYS & C. R and P & Result of Test \\
\hline Hypothesis 1 & The better strategy of differentiations, the better competitive advantages achieved. & C. $\mathrm{R}=3,436 P=0,000^{* * *}$ & Accepted \\
Hypothesis 2 & $\begin{array}{l}\text { The better organizational culture, the better competitve advantage of the university } \\
\text { achieved. }\end{array}$ & C. $\mathrm{R}=2,413 P=0,016^{* *}$ & Accepted \\
Hypothesis 3 & The better the university's competitive advantage, the better performance. & C. $\mathrm{R}=3,751 P=0,000^{* * *}$ & Accepted \\
\hline
\end{tabular}

***Significant at 0.001 (2-tailed), **significant at 0.01 (2-tailed), *significant at 0.1 (2-tailed).

Source: primary data, proceed 2010

Hypothesis one in this study was the effect of the differentiation strategy on competitive advantage, which is the better strategy of differentiations, the better competitive advantages achieved. The data processing results show the value of $\mathrm{CR}$ (Critical Ratio) for the influence of differentiation strategy on competitive advantage ie 3.436 with a P (Probability) value of 0.000 . Both of these values are qualified, ie above 1.96 for CR (CriticalRatio) and under 0.05 for the value of $\mathrm{P}$ (Probability). So it can be concluded that the first hypothesis this study is accepted.

Hypothesis two in this study is the influence of organizational culture on the competitive advantage of university, the better organizational culture, the better competitive advantage of the university achieved. The data processing result shows the value of CR (Critical Ratio) for the influence of organizational culture on university performance ie 2.413 with $\mathrm{P}$ (Probability) value ie 0.016 . Both of these values are qualified, ie above 1.96 for CR (Critical Ratio) and below 0.05 for the value of $\mathrm{P}$ (Probability). So it can be concluded that the second hypothesis in this study is accepted.

Hypothesis three in this study is the influence of competitive advantage on university performance. The better competitive advantage, the better university performance. The data processing result shows that the value of CR (Critical Ratio) for the influence the competitive advantage on university performance is 3.751 with $\mathrm{P}$ (Probability) value ie 0.000 . Both of these values are qualified, ie above 1.96 for CR (CriticalRatio) and below 0.05 for the value of $P$ (Probability). So it can be concluded that the third hypothesis in this study is accepted.

\section{Discussions and Conclusions}

This study was attempted to answer how the university competitive advantage can affect the performance in UNNES (Semarang State University) through the implementation of differentiation strategy and good organizational culture. The first contribution of this study is that the differentiation strategic and organizational culture have positive impact on competitive advantage and performance of Semarang state University. Differentiation strategic are relevant for the competitive advantage in Semarang state University. This is consistent with the theory advanced by (Porter, 1980; 1985, 
Kotha and Orne, 1989; Baines and Langfield-Smith, 2003), Strategic differentiation are significant in achieving a sustainable competitive advantage and performance in a fast moving business. A differentiation strategy involves the firm creating a product and service, which is considered unique in some aspect that the customer values because the customer's needs are satisfied. Nevertheless, past researches have shown that a number of the manufacturing organizationals view the differentiation strategy as a more important and distinct means to achieve competitive advantage in constrict to a low cost strategy.

Second significant contribution of this study is organizational culture also stands out as one of the components that are important to sustain competitive advantage. Consistent of an organizational culture learning can develop the ethical environment, which in turn can develop people in the organizational with the shared belief, trust and team coordination for critical success (Kotler \& Keller, 2006). Based on the result analysis, empirical corroboration in Semarang State University shows that differentiation strategic and organizational culture have positive impact on competitive advantage and performanceon Semarang state university. a significant relationship exist between organizational culture and competitive advantage are two different constructs with an apparently complex relationship (Ma, 2000). It has been argued that achieving a position of competitive advantage is a precursor to the significant performance of an organizational culture (Barney, 1991) and that competitive advantage results from a long list of varying factors which include operational efficiencies, mergers, acquisitions, levels of diversification, types of diversification, organizational structures, top management team composition and style, human resource management, manipulation of the political and social influences intruding upon the market, conformity to various interpretations of socially responsible behaviors and so forth.

Third contribution of this study is differentiation strategic have positif impact on performance institutional. Sustaining competitive advantage have positive impact on performance institutional because competitive advantage has taken centre stage in discussions of business strategy, a definite definition of the term is quite elusive. However a common theme has remained 'value creation'. According to Porter (1985), 'competitive advantage is at the heart of a firm's performance in competitive markets' This implies that, competitive advantage means having low costs, differentiation advantage, or a successful focus strategy. Also, he argues that 'competitive advantage grows fundamentally out of value a firm is able to create for its buyers that exceeds the firm's cost of creating it' (Porter, 1986). Porter's arguments reflect thecommon strengths, weaknesses, opportunities, and threats (SWOT) framework for assessing competitive advantage. Competitive advantage stems from a firm's ability to leverage its internal strengths to respond to external environmental opportunities while avoiding external threats and internal weaknesses (Mooney, 2007).

The results of this study provide input to the Semarang state University to pay more attention to the policies directed towards the planning and implementation of good differentiation strategic and organizational culture, especially to make a plan of strategic policy that will determine the sustainability of competitive advantage and performance institutional because competitive advantage is at the heart of institution performance. especially to replicability that will determine the sustainability of the university, as this can also increase the University competitive advantage because the increase of replicability to customers by employees and lecturers in the name of company sustainability will be able to improve the company performance. But that does not mean the application of organizational culture is not effective, only it has smaller influence than the variable differentiation strategy. Organizational culture have impact to competitive advantage. Oppeness is one determinant aspect from organizational culture to gain competitive advantage. then it is better if the differentiation strategy become top priority to improve competitive advantage in UNNES and organizational culture comes after. This research study further demonstrates that differentiation strategic could be used as a tool for achieving competitive advantage and enhancing greater organizational performance. Without a sustainable competitive advantage, above average performance is usually a sign of harvesting (Porter, 1985).

This research also contains some limitations. First, this study just explores effects and relationship of differentiation strategic, organizational culture, competitive advantage and performance with many other topics left unexplored. Further researches should explore deeper into other aspects. Second, based on the theoretical assumption, this study has considered an adaptation from some journal articles, but not empirically tested whether this assumption is pertinent. Finally this study employs static and cross-sectional data, which has in evitable drawbacks in reflecting the function and evolution of differentiation strategic, organizational culture, competitive advantage and performance management. The application of panel data may be used in the following studies.

\section{Aknowledgements}

The research is based upon work supported by the National Social Science (NSC) fund key project N0.15AZD063 and the Fundamental Research Funds for the Central of Semarang State University.

\section{References}

[1] Astuti, C. D. (2003). Relationship communication quality and stress: Indonesia Journal Psychology, 52-60.

[2] Barney, Jay, (1991). "Firm Resources \& Sustainable Competitive Advantage", Journal of management, Vol. 17, pp. 99-120.

[3] Baines, A. \& Langfield-Smith, K. (2003). "Antecedents to management accounting change: a structural equation approach", Accounting, Organizationals and Society, 28: 675-98. 
[4] Blustain, H., P. Bonser and Rubach, (2007). Assessing the New Competitive Landscape in R. Katz \& Associates (Eds), Dancing with the Davil: Information Technology and the New Competition in Higher Education, pp. 51-71, San Francisco: Jossey-Bass, Inc.

[5] Brien, W. J. (1998), Capacity Costing Approaches for Construction Supply-Chain Management, Stanford University Press.

[6] Chao Shun Huy, (1991). A research on the relationship among market orientation, absorptive capability, organizational innovation climate and innovative behavior inTaiwan's manufacturing industry. African Journal of Business Management, 5(19), 7855-7863.

[7] Direktorat Jendral Pendidikan Tinggi, (2003). Higher Education Long Term Strategy 2003-2010, Direktorat Jendral Pendidikan Tinggi Republik Indonesia.

[8] Denison, D. R, (1990). Corporate culture and organizational effectiveness. New York: John Wiley \& Sons.

[9] Day George S and Wensley Robins, (1988) Assessing Advantage: A Framework for Diagnosing Competitive Superiority. Journal of Marketing, Vol. 52, No. 2, pp. 1-20.

[10] Ferdinand, Agusty, (2003), Sustainable Competitive Advantage, Universitas Diponegoro, Semarang.

[11] Freed JE \& Klugman MR. (1997), Quality Principles and Practices In Higher Education: Different Questions For Different Times American Council On Education Phoenix: oryx Press.

[12] Fahy \& Smithee, (1999), "Sustainable Competitive Advantage In Service Industries: A Conceptual Model and Reseach Proposition”, Journal Of Marketing, Vol. 57, pp. 83-99.

[13] Gordon, Peter; Richardson, Harry W, (1997) American Planning Association. Journal of the American Planning Association; 63, 1; pg. 95.

[14] Hair J. F., A. Rolp., Tatham E., Ronald L., and Black William C., (2010). Multivariate Data Analysis, Fifth Edition, New York: Prentice-Hall International Inc.

[15] Hitt, M. A., Ahlstrom, D., Dacin, M. T., \& Levitas, E, (2001). The Economic and Institutional Context of International Strategic Alliance partner Selection: China vs Russia. Paper Presented at Academy of Management meetings. August, washington, DC.

[16] Horngren CT, Harrison WT (1992), Accounting, 2 edn. Prentice-Hall, Englewood Cliffs.

[17] Hoffman, D. D. (2000), Visual intelligence: How we create what we see. New York: W. W. Norton.

[18] Jawa Pos, (2006), Four universities in Indonesia achieved good rank in the world: Be a campus reserach. Jawa Pos, Surabaya: 13 November.

[19] Kotha, S. \& Orne, D. (1989). Generic manufacturing strategies: A conceptual synthesis, Strategic Management Journal (1986-1989). 10.3: 211.

[20] Kaplan, Norton, (1996). Using the Balance Score Card as Strategic Management System, Harvard business school.

[21] Kotler, Jhon P \& James A Hesket, (1997), Corporate Culture \& Performance. PT. Prenhelido, The free pres.
[22] Kotler, Keller, (2000). Competence Based, Journal management, Vol. 18, pp. 77-91.

[23] Kutcher, (2000). "Design Management: Managing Design, Strategy, Process and Implementation", Journal Management Strategy, Vol. 15.

[24] Keats Barbara W: Hitt Michael A, (1988) A Causal Model of Linkages Among Environmental Dimensions, Macro Organizational Characteristics, and performance, The Academy of Management Journal, Vol 31, No 3, pp. 570-598.

[25] Kline, R. B, (1998). Priciples and practices of structural equation modeling, New York, N. Y.: The Giuldford Press.

[26] Kleinbaum, D. G., Kupper, \& Muller, K. E, (1998). Applied regression analysis and other multivariate methods. Belmont, CA: Duxbury Press.

[27] Lado, A. A, (1994). Human Resource Systems and Sustained Competitive Advantage: Competence-Based perspective/A. A. Lado, MC Wilson Academy of Management Review, 1994, Vol 19, No.4, p. 699-727.

[28] Ma, H. (2000). Competitive advantage and firm performance. Competitiveness Review, Vol. 10 Issue 2.

[29] Mulyadi, (2001). Balanced Scorecard; Contemporer tools management for increase account firm double performance, Cetakan Kesatu, Penerbit Salemba Empat, Jakarta.

[30] Mc Grath, R. G., \& Mac Millan, I. C, (1997). The Entrepreneurial Mindset. Cambridge, MA: Harvard Businnes School Press.

[31] Mooney, A. (2007). Core Competence, Distinctive Competence, and Competitive Advantage: What Is the Difference? Journal of EducationBusiness, vol. 83 Issue 2.

[32] Jill L. Mckinnon, Anne Wu and Chee W. Chow, (2003). Cultural influences on adaptation to fluid workgroups and teams. Journal of international business studies; 31 (2000), 3, pp. 489-505.

[33] O'Reilly, (1991), People \& organizational culture. A profile comparison approach to assessing person organizational. Academy of management journal, Vol. 34, pp. 487-516.

[34] Porter, M. E. (1985). Competitive Advantage: Creating and Sustaining Superior Performance Free Press, New York.

[35] Porter, Michael E, (1995), Competitive advantage: Creating and sustaining superior performance. New York.

[36] Porter, M. E. (1986). Competition in global industries. Harvard Business School Press, Boston.

[37] Peters, Tom J. \& Waterman, Robert H. (1996), In Search of Excellence - Lessons from America's Best-Run Companies, HarperCollins Publishers, London.

[38] Robbins, (1996), Organizational Behavior Concept. Prentice Hall, inc.

[39] Sashi \& Stern, (1995), "Product Differentiation and Market Performance in Producer Goods Industries", Journal Of Business Research, Vol. 33, pp. 115-127.

[40] Stern. P. C., Diet Z, T., Kalof, L., \& Guagnan0, G. A (1995). Values, beliefs and proenvironmental action: Attitude formation toward emergent attitude objects. Journal of Applied Social Psychology, 25, 1611-1636. 
[41] Schein, Edgar H, (1992). Organizational Culture \& Leadership. San Fransisco.

[42] Susanto, (2001). "Management Information System": Concept and development, Bandung. Lingga Jaya.

[43] Scholz, Z. (1987): Corporate culture and strategy - problem of strategic fit, Journal Long Range Planning, Vol. 20, No. 4.
[44] Susanto, (2000), Human resource management research method. PT Graha Ilmu. Yogyakarta.

[45] Yeni, Y. H. (2007). The role of market orientation in HEIs in Indonesia in relation to improving institutional performance. DBA thesis, Southern Cross University, Australia.

[46] http://www.webometric.com. 